\section{Stanovení somatických kolifágů a koncentrační metody používané pro vzorky vod s jejich nízkým výskytem}

\section{JANA ZUZÁKOVÁ, DAVID JANÁK, JANA ŘíHOVÁ AMBROŽOVÁ}

Klíčová slova: somatické kolifágy - koncentrační metody indikátory fekálního znečištění - kvalita pitné vody opětovné využití odpadních vod

\section{SOUHRN}

Somatické kolifágy jsou novým ukazatelem kontroly účinnosti úpravy a čištění vody zmiňovaným ve směrnici Evropského parlamentu a Rady (EU) 2020/2184 ze dne 16. prosince 2020 o jakosti vody určené k lidské spotřebě a i v nařízení Evropského parlamentu a Rady (EU) 2020/741 ze dne 25. května 2020 o minimálních požadavcích na opětovné využívání vody. Z tohoto důvodu bude nezbytné v blízké době postupně zavádět metodu stanovení somatických kolifágů ve vodách do některých provozních či jiných laboratoří. Možnost využití kultivačního postupu v souladu s postupem v normě ČSN EN ISO 10705-2 [3] je řešena od roku 2019 v mikrobiologické laboratoři Ústavu technologie vody a prostředí na VŠCHT Praha. Somatické kolifágy byly zjištovány ve vzorcích různě zatížených vod, resp. v povrchových vodách, odpadních vodách (odtoky z čistíren odpadních vod) a šedých vodách. Experimentálně byly také zkoušeny a ověřovány vybrané koncentrační metody (flokulace hydroxidem hořečnatým a membránová filtrace), které je nutné používat pro vzorky vod s nízkým výskytem somatických kolifágů (<3 PTJ/ml). Na základě provedených testů bylo zjištěno, že metoda membránové filtrace s využitím elektronegativních filtrů vykazuje vyšší účinnost při zkoncentrování somatických kolifágů ze vzorku vody než flokulace hydroxidem hořečnatým.

\section{ÚVOD}

Z vodárenské praxe jsou za posledních několik let známy případy kontaminace pitné vody virovým agens, at' už se jednalo o prípady spojené s výskytem enterovirů, norovirů, nebo adenovirů. Tyto prípady byly tiskem a odbornou veřejností medializované. Viry jsou všeobecně považovány za více rezistentní živé systémy (organismy) vůči biologickým i fyzikálně-chemickým vlivům prostředí než bakterie. I přes rizikovost tohoto mikroorganismu není požadavek na jeho stanovení v rámci prováděných mikrobiologických analýz vody zohledněn např. vyhláškou č. 252/2004 Sb., v platném znění, kterou se stanoví hygienické požadavky na pitnou a teplou vodu a četnost a rozsah kontroly pitné vody. Většinu

\section{Concentration} and enumeration methods of somatic coliphages in water samples

\section{JANA ZUZÁKOVÁ, DAVID JANÁK, JANA ŘíHOVÁ AMBROŽOVÁ}

Keywords: somatic coliphages - concentration methods indicators of fecal pollution - drinking water quality wastewater reuse

\section{SUMMARY}

Somatic coliphages are a new indicator for monitoring the efficiency of water treatment and purification in the Directive (EU) 2020/2184 of the European Parliament and of the Council of 16 December 2020 on the quality of water intended for human consumption and in Regulation (EU) 2020/741 of the European Parliament and of the Council from 25 May 2020 on minimum requirements for water reuse. For this reason, it will be necessary in the near future to gradually introduce a method for the determination of somatic coliphages in water in some operational or other laboratories. The possibility of using the cultivation procedure in accordance with the procedure in the ČSN EN ISO 10705-2 standard has been addressed since 2019 in the microbiological laboratory of the Department of Water Technology and Environmental Engineering at the University of Chemistry and Technology in Prague. Somatic coliphages were detected in samples of differently polluted waters, specifically in surface waters, wastewaters (effluents from wastewater treatment plants) and grey waters. Selected concentration methods (magnesium hydroxide flocculation and membrane filtration), which must be used for water samples with a low concentration of somatic coliphages $(<3 \mathrm{PFU} / \mathrm{ml})$, were also tested and verified experimentally. Based on the performed tests, it was found that the membrane filtration method using electronegative filters shows higher efficiency in concentrating somatic coliphages from a water sample than flocculation with magnesium hydroxide.

\section{INTRODUCTION}

In the last few years, cases of contamination of drinking water with viral agents have been known from water supply practice, whether these were cases associated with the occurrence of enteroviruses, noroviruses, or adenoviruses. These cases were publicized by the press and the professional public. Viruses are generally considered to be more resistant living systems (organisms) to biological and physico-chemical environmental influences than bacteria. Despite the danger of this microorganism, the requirement for its determination within the performed microbiological analyses of water is not taken into account, 
virů není možné kultivačním postupem detekovat, namísto nich se uplatňují metody molekulární biologie (např. PCR = polymerázová řetězová reakce), které vyžadují adekvátní vybavení laboratoře, což je patřičně i ekonomicky nákladné Stanovení některých typů virů kultivačně je na provedení v provozní mikrobiologické laboratoři náročné, protože jsou zapotřebí prítomné hostitelské buňky vybraných kmenů bakterií a optimalizované postupy.

Somatické kolifágy jsou $v$ současné době velmi diskutovaným tématem $\checkmark$ oblasti kontroly kvality vody, protože vykazují určitou morfologickou podobnost jako lidské enterické viry a je možné na ně pohlížet jako na případné indikátorové organismy př́tomnosti virové kontaminace ve vodách. Kvưli stále se zvyšujícím požadavkům na kvalitu pitné vody i tlakům společnosti na opětovné využívání vyčištěných odpadních vod, byly somatické kolifágy legislativně navrženy jako nové ukazatele pro kontrolu účinnosti úpravy a čištění vody. Z toho důvodu je velice žádoucí kontrola jejich prítomnosti v některých typech vod, zejména ke kontrole vody určené pro lidskou spotřebu. Somatické kolifágy jsou skupinou nepatogenních bakteriálních virů tzv. „bakteriofágů”, které infikují buňky koliformních bakterií (skupina Enterobacteriaceae), a zejm. pak buňky bakterie druhu Escherichia coli. Přirozeným prostředím somatických kolifágů je, stejně jako pro bakterie Escherichia coli, gastrointestinální trakt člověka a teplokrevných organismů.

Dne 12. 1. 2021 vstoupila v platnost směrnice Evropského parlamentu a Rady (EU) 2020/2184 ze dne 16. 12. 2020 o jakosti vody určené k lidské spotřebě, která je kompletně přepracovanou novelou stávající směrnice č. 98/83/EC. Předpoklad implementace této směrnice do národních právních předpisư je konec roku 2022 až začátek roku 2023

Účelem směrnice pro pitnou vodu je ochrana zdraví spotřebitelů před následky užívání znečištěné vody a zajištění zdravotní nezávadnosti pitné vody prostřednictvím definovaných norem kvality, které jsou členské státy EU povinné dodržovat. Revize se mimo jiné věnovala právě aktualizaci seznamu ukazatelů kvality pitné vody, které již neodpovídaly současným poznatkům. Somatické kolifágy jsou novým ukazatelem, který bude muset být sledován v rámci provozního monitorování účinnosti procesu úpravy pitné vody, pokud ve zdroji surové vody bude zjištěno > 50 PTJ/100 ml (PTJ = plak tvořící jednotku) [1].

Somatické kolifágy jsou rovněž zmiňovány v novém nařízení Evropského parlamentu a Rady (EU) 2020/741 ze dne 25. května 2020 o minimálních požadavcích na opětovné využívání vody [2]. Díky tomuto nařízení by mělo být pro členské státy Evropské unie (EU) snadnější opětovně využívat vyčištěné městské odpadní vody, a to zejména k závlahám v zemědělství. Kromě minimálních požadavků na kvalitu recyklované vody, stanovuje nařízení také četnost rutinního a validačního monitorování. Somatické kolifágy je nutné posuzovat v rámci validačního monitorování zařízení u kategorie s nejpřísnějšími požadavky na kvalitu vody (třída A, pro kterou platí: „Všechny potravinářské plodiny konzumované za syrova, jejichž jedlá část je v prímém kontaktu s recyklovanou odpadní vodou, a kořenové plodiny konzumované za syrova.") [2]. Smyslem validačního monitorování je hodnocení účinnosti daného zařízení v odstranění vybraných indikátorových organismů patogenních bakterií, prvoků a virů.

Po vyhlášení přijatých legislativních dokumentů v Úředním věstníku EU mají následně členské státy EU povinnost zapracovat př́slušné změny do svých právních předpisů. Nařizení EU je možné přímo aplikovat v členských státech EU. Metodu stanovení somatických kolifágů ve vodách bude tedy nezbytné zavést do některých provozních či jiných laboratoří, a tyto laboratoře budou muset následně věnovat určitý čas optimalizaci metody.

Možnost využití kultivačního postupu v souladu s postupem v normě ČSN EN ISO 10705-2 [3] je soustavně řešena od roku 2019 v mikrobiologické laboratoři Ústavu technologie vody a prostředí na VŠCHT Praha. Metoda uvedená touto normou se použivá pro detekci somatických kolifágů v různě zatížených vodách. Při zkoušení postupu stanovení podle uvedené normy se zjištovaly možnosti a případná uplatnění metody specifikované normou [3] pro for example, by Decree No. 252/2004 Coll., as amended, which sets hygienic requirements for drinking and hot water and the frequency and scope of drinking water control. Most viruses cannot be detected by cultivation procedure: molecular biology methods are used instead (e.g., PCR = polymerase chain reaction), which require adequate laboratory equipment, which is expensive. Determination of some types of viruses by cultivation is difficult to perform in an in-house microbiological laboratory because host cells of selected bacterial strains and optimized procedures are required.

Somatic coliphages are currently a much-discussed topic in the field of water quality control, as they show some morphological similarity to human enteric viruses and can be seen as possible indicator organisms for the viral contamination in water. Due to the ever-increasing demands on drinking water quality and the society's pressure for the reuse of treated wastewater, somatic coliphages were legislatively proposed as new indicators to monitor the efficiency of water treatment and purification. For this reason, it is highly desirable to monitor their presence in certain types of water, especially water intended for human consumption. Somatic coliphages are a group of non-pathogenic bacterial viruses called "bacteriophages", which infect cells of coliform bacteria (Enterobacteriaceae group) and, in particular, cells of the bacterium Escherichia coli (E. coli). The natural environment of somatic coliphages is, as for $E$. coli bacteria, the gastrointestinal tract of humans and warm-blooded organisms.

The Directive of the European Parliament and of the Council (EU) 2020/2184 from 16 December 2020 on the quality of water intended for human consumption came into force on 12 January 2021, which is a completely recast amendment to the Directive 98/83/EC. The precondition for the implementation of this Directive into national legislation is the end of 2022 to the beginning of 2023.

The purpose of the Drinking Water Directive is to protect consumer health from the consequences of polluted water use and to ensure the safety of drinking water through defined quality standards, which EU Member States are required to comply with. Among other things, the revision focused on updating the list of drinking water quality indicators, which no longer corresponded to current knowledge. Somatic coliphages are a new indicator that will have to be checked in the operational monitoring of the drinking water treatment process effectiveness if $>50 \mathrm{PFU} / 100 \mathrm{ml}$ (PFU = plaque forming unit) is detected in the raw water source [1].

Somatic coliphages are also mentioned in the new Regulation 2020/741 of the European Parliament and of the Council (EU) of 25 May 2020 on minimum requirements for water reuse [2]. This regulation should make it easier for the Member States of the European Union (EU) to reuse treated urban wastewater, especially for irrigation in agriculture. In addition to the minimum requirements for the quality of recycled water, the regulation also stipulates the frequency of routine and validation monitoring. Somatic coliphages must be assessed as part of the validation monitoring of the device for the category with the most stringent water quality requirements (Class A, for which the following applies: "All food crops consumed raw, the edible part of which is in direct contact with recycled wastewater, and root crops consumed raw") [2]. The purpose of validation monitoring is to evaluate the effectiveness of the device in removing selected indicator organisms of pathogenic bacteria, protozoa, and viruses.

Following the publication of the adopted legislative documents in the EU Official Journal, EU member states are subsequently obliged to incorporate the relevant changes into their legislation. EU regulations can be directly applied in EU member states. The method of determining somatic coliphages in water will therefore need to be introduced in some operational or other laboratories, and these laboratories will then have to devote some time to optimize the method.

The possibility of using the cultivation procedure in accordance with the procedure in the standard ČSN EN ISO 10705-2 [3] has been systematically dealt with since 2019 in the microbiological laboratory of the Department of Water Technology and Environmental Engineering at the University of Chemistry and Technology in Prague. The method introduced by this standard is used for 
běžný mikrobiologický monitoring stavu mikrobiální kontaminace (resp. fekálního znečištění) povrchových vod, odpadních vod (odtoky z čistíren odpadních vod) a šedých vod. Pro zajímavost byla do testů zařazena i pitná voda. Experimentálně byly zkoušeny a ověřovány koncentrační metody, které je nezbytné používat pro vzorky vod s nízkým výskytem somatických kolifágů (<3 PTJ/ml) a jsou uvedené v normě ČSN ISO 10705-3 [4] (platné od 1. 12. 2020). Postupy stanovení a problémy spojené s metodami uvedenými v normě ČSN EN ISO 10705-2 [3] a v normě pro koncentrační metody ČSN ISO 10705-3 [4] jsou diskutovány dále $v$ príspěvku.

\section{METODIKA}

Za účelem stanovení somatických kolifágů byly odebírány vzorky povrchových vod, odtoků z ČOV, šedých vod a pitné vody. Somatické kolifágy byly následně stanovovány podle postupu uvedeného v normě ČSN EN ISO 10705-2 [3], Část 2: Kvantitativní stanovení somatických kolifágů. Vzhledem k tomu, že zmíněná metoda je vhodná spíše pro vody s vyšším výskytem somatických kolifágů, byly experimentálně ověřovány vybrané koncentrační metody navrhované v príloze A normy ČSN ISO 10705-3 [4], Část 2: Validace metod pro zkoncentrování bakteriofágů z vody (metoda membránové filtrace a flokulace hydroxidem hořečnatým).

\section{POSTUP STANOVENÍ SOMATICKÝCH KOLIFÁGŮ}

Metoda stanovení podle ČSN EN ISO 10705-2 [3] spočívá v kultivaci a udržování příslušného hostitelského kmene Escherichia coli, který je následně použit pro stanovení somatických kolifágů pomocí dvouvrstvé plakové titrace. Pro účely testování byl hostitelský kmen Escherichia coli získán ze sbírky Státního zdravotního ústavu v Praze, kde je veden pod označením CNCTC 5005. Z obdrženého lyofilizovaného referenčního hostitelského kmene byla postupně pomocí modifikovaného Scholtensova média (MSB) připravena štoková a pracovní kultura. Požadovaná hustota $\left(10^{8} \mathrm{KTJ} / \mathrm{ml}\right)$ buněk pracovní kultury byla před stanovením somatických kolifágů kontrolována spektrofotometricky pomocí měření absorbance, a to na základě předem provedené kalibrace mezi absorbancí a počtem kolonií narostlých na modifikovaném Scholtensovu médiu MSA.

Samotné stanovení somatických kolifágů bylo následně prováděno podle standardního postupu uvedeného $v$ normě [3] s drobnými modifikacemi. K temperování roztopeného polotekutého Scholtensova média (sSMSA) s prídavkem chloridu vápenatého byla použita vodní lázeň o teplotě $45^{\circ} \mathrm{C}$. Do sterilních bakteriologických zkumavek umístěných ve vodní lázni bylo postupně pipetováno 2,5 ml ssMSA média, $1 \mathrm{ml}$ inokulační kultury hostitelského kmene E. coli a $1 \mathrm{ml}$ analyzovaného vzorku. Směs byla promíchána a následně byla nalita na povrch kompletního média MSA v Petriho misce. Po zatuhnutí byly misky inkubovány v závěsné poloze při teplotě $37^{\circ} \mathrm{C}$ po dobu cca 18 h. Somatické kolifágy tvoří na povrchu média viditelné zóny projasnění, tzv. plaky, které se odečítají a následně vyjadřují jako počet plaků tvořících jednotky (PTJ) v objemové jednotce. Pro kontrolu správnosti provedení bylo zároveň prováděno slepé stanovení, kterým je směs inokulační kultury hostitelského kmene a polotekutého ssMSA média.

\section{KONCENTRAČNÍ METODY}

Účinnosti vybraných koncentračních metod, v tomto prípadě membránové filtrace a flokulace hydroxidem hořečnatým, byly experimentálně zkoušeny na reálných vzorcích odpadních vod odebíraných na odtoku z městské the detection of somatic coliphages in differently loaded waters. When testing the determination procedure according to the said standard, the possibilities and possible applications of the method specified by the standard [3] for routine microbiological monitoring of the state of microbial contamination (or fecal contamination) of surface waters, wastewater (effluent from wastewater treatment plants), and grey water were identified. For interest, drinking water was also included in the tests. Concentration methods that must be used for water samples with a low incidence of somatic coliphages ( $<3$ PFU/ml) and are listed in the standard ČSN ISO 10705-3 [4] (valid from 1 December 2020) were tested and verified experimentally. Determination procedures and problems associated with the methods specified in the standard ČSN EN ISO 10705-2 [3] and in the standard for concentration methods ČSN ISO 10705-3 [4] are discussed further in the paper.

\section{METHODOLOGY}

In order to determine somatic coliphages, samples were taken of surface water, effluents from WWTPs, grey water, and drinking water. Somatic coliphages were subsequently determined according to the procedure specified in the standard ČSN EN ISO 10705-2 [3], Part 2: Quantitative determination of somatic coliphages. Due to the fact that the method is more suitable for waters with a higher incidence of somatic coliphages, selected concentration methods proposed in Annex A of the standard ČSN ISO 10705-3 [4], Part 2: Validation of methods for concentration of bacteriophages from water (method of membrane filtration and flocculation with magnesium hydroxide) were verified experimentally.

\section{PROCEDURE FOR DETERMINING SOMATIC COLIPHAGES}

The method of determination according to ČSN EN ISO 10705-2 [3] consists of cultivating and maintaining the appropriate host strain of E. coli, which is subsequently used for the determination of somatic coliphages by two-layer plaque titration. For testing purposes, the E. coli host strain was obtained from the collection of the State Institute of Public Health in Prague, under the designation CNCTC 5005. From the obtained lyophilized reference host strain, a stock and working culture was gradually prepared using modified Scholtens medium (MSB). The required density $\left(10^{8} \mathrm{CFU} / \mathrm{ml}\right)$ of working culture cells was checked spectrophotometrically by absorbance measurements prior to somatic coliphage determination, based on a pre-calibration between absorbance and number of colonies grown on modified MSA Scholtens medium.

The determination of somatic coliphages per se was subsequently performed according to the standard procedure given in the standard [3] with minor modifications. To temper the molten semi-liquid Scholtens medium (sSMSA) with the addition of calcium chloride, a $45^{\circ} \mathrm{C}$ water bath was used. In total $2.5 \mathrm{ml}$ of ssMSA medium, $1 \mathrm{ml}$ of inoculum culture of the $E$. coli host strain, and $1 \mathrm{ml}$ of the analysed sample were sequentially pipetted into sterile bacteriological tubes placed in a water bath. The mixture was stirred and subsequently poured onto the surface of the complete MSA medium in a Petri dish. After solidification, the dishes were incubated in a suspended position at $37^{\circ} \mathrm{C}$ for about 18 hours. Somatic coliphages form visible zones of brightness on the surface of the medium, so-called plaques, which are read and subsequently expressed as the number of plaques forming units (PFU) in a unit of volume. To check the correctness of the procedure, a blank determination was also performed, which is a mixture of an inoculum culture of the host strain and a semi-liquid ssMSA medium. 
mechanicko-biologické čistírny odpadních vod (ČOV). Obě metody byly testovány metodou standardního př́ídavku. Pro zjištění účinnosti flokulace bylo dávkováno $10 \mathrm{ml}$ vzorku odtoku z ČOV do $90 \mathrm{ml}$ odstáté kohoutkové vody. V př́padě testování membránové filtrace byl do $100 \mathrm{ml}$ (případně $90 \mathrm{ml}$ ) destilované vody pipetován $1 \mathrm{ml}$ (prípadně $10 \mathrm{ml}$ ) vzorku odtoku z ČOV. Ve vzorku odtoku z ČOV, tzn. ve vzorku pro príldavek, byly paralelně stanovovány somatické kolifágy podle normy ČSN EN ISO 10705-2 [3]. Takto prripravené suspenze byly následně předupraveny jednotlivými koncentračními metodami pro zachycení kolifágů.

Metoda flokulace hydroxidem hořečnatým spočívá v separaci kolifágů zachycených do vznikajících vloček. K testovanému objemu připraveného vzorku jsou postupně přidávány roztoky chloridu hořečnatého (1 mol/l) a hydrogenfosforečnanu draselného $(1 \mathrm{~mol} / \mathrm{l})$, a to $v$ objemu uvedeném $v$ normě ČSN ISO 10705-3 [4]. Po kapkách se přidává roztok hydroxidu sodného (2 mol/l) do vzniku viditelného zákalu, přičemž je současně kontrolována hodnota pH, která by neměla přesahovat hodnotu 8,6. Suspenze se pomalu míchá po dobu cca 15 minut, príčemž vznikající vločky následně sedimentují cca 30 minut. Po opatrném odtažení supernatantu je rídký sediment zkoncentrován pomocí centrifugace při malé rychlosti (relativní centrifugační zrychlení RCF = $1000 \mathrm{~g}$ ) po dobu 15 minut. Po slití supernatantu je sediment resuspendován pomocí peptonové vody s chloridem sodným a intenzivním třepáním. Stanovení somatických kolifágů následně probíhá podle normy ČSN EN ISO 10705-2 [3]. V rámci testování účinnosti koncentrační metody byl rovněž sledován vliv hodnoty pH při flokulaci (hodnoty pH: 7,6; 8,0; 8,3; 8,6 a 9,0).

Metoda membránové filtrace spočívá ve filtraci daného objemu vzorku přes elektronegativní filtr ze směsi acetátu celulózy a nitrátu celulózy, o velikosti pórů 0,22 $\mu \mathrm{m}$ a průměru $47 \mathrm{~mm}$. Filtraci předchází prídavek roztoku chloridu hořečnatého. Filtr je následně rozstříhán na cca 8 menších částí a vložen do skleněné baňky s elučním roztokem ( $1 \%$ hovězí extrakt, 0,5 mol/l $\mathrm{NaCl}$, $3 \%$ Tween 80), který se vloží do ultrazvukové lázně na cca 4 minuty. Stanovují se současně somatické kolifágy uvolněné do elučního roztoku a zachycené na filtrech. V rámci testování účinnosti metody byl sledován také vliv složení elučního roztoku (zde: $1 \%$ hovězí extrakt, $0,5 \mathrm{~mol} / / \mathrm{NaCl} ; 1 \%$ hovězí extrakt, $0,5 \mathrm{~mol} / \mathrm{l} \mathrm{NaCl}, 3 \%$ Tween $80 ; 3 \%$ hovězí extrakt, 0,5 mol// NaCl; $3 \%$ hovězí extrakt, 0,5 mol// NaCl, 3 \% Tween 80).

\section{VÝSLEDKY A DISKUSE}

Výskyt somatických kolifágů ve vodním prostředí obvykle indikuje znečištění zpưsobené zviřrecími nebo lidskými fekáliemi. Přestože jsou prrirozenými hostitelskými kmeny somatických kolifágů bakterie druhu Escherichia coli, bylo některými studiemi zjištěno, že pro svou replikaci mohou využívat i jiné příbuzné bakteriální druhy, které nejsou fekálního původu [5]. Porovnání výskytu somatických kolifágů v různě zatížených vodách, resp. v pitných vodách, povrchových vodách, šedých vodách a ve vyčištěných odpadních vodách (odtok z ČOV) je patrné v tabulce 1. Stanovení bylo provedeno podle postupu uvedeného v normě ČSN EN ISO 10705-2 [3]. V testovaných povrchových vodách se počty somatických kolifágů pohybovaly v rozmezí od 0 do 25 PTJ/ml. Vzhledem k tomu, že byly odebírány a analyzovány různé typy povrchových vod (tekoucí, stojaté) z odlišných lokalit, není uváděna prưměrná hodnota počtu PTJ. Z testovaných vod byly nejvyšší počty somatických kolifágů nacházeny v odtocích z čistíren odpadních vod. Celkem bylo otestováno šest různých ČOV, přičemž nálezy somatických kolifágů se $v$ odtocích pohybovaly $\vee$ rozmezí od 8 do 84 PTJ/ml s průměrnou hodnotou cca $42 \mathrm{PTJ} / \mathrm{ml}$. V odpadních vodách na přitoku ČOV nebyly laboratorně somatické kolifágy zatím zjištóvány (důvodem je zvýšený výskyt doprovodné mikroflóry, která ruší odečet plaků při vyhodnocování). Pro doplnění, odborná literatura uvádí počty somatických kolifágů na přítocích do ČOV v rozsahu od 5·10 ${ }^{6}$ do 5·107 PTJ/100 ml [6]. U vzorků šedých vod, ve kterých

\section{CONCENTRATION METHODS}

The efficiencies of selected concentration methods, in this case, membrane filtration and flocculation with magnesium hydroxide, were experimentally tested on real wastewater samples taken from effluent from the municipal mechanical-biological wastewater treatment plant (WWTP). Both methods were tested by the standard addition method. To determine flocculation efficiency, $10 \mathrm{ml}$ of the WWTP effluent sample was dosed in $90 \mathrm{ml}$ of standing tap water. In the case of membrane filtration testing, $1 \mathrm{ml}$ (or $10 \mathrm{ml}$ ) of a sample of the effluent from the WWTP was pipetted into $100 \mathrm{ml}$ (or $90 \mathrm{ml}$ ) of distilled water. In the WWTP effluent sample, i.e., in the sample for addition, somatic coliphages were determined in parallel according to the standard ČSN EN ISO 10705-2 [3]. The suspensions thus prepared were subsequently pre-treated by individual concentration methods to capture coliphages.

The method of flocculation with magnesium hydroxide consists of the separation of coliphages captured in the resulting flakes. Solutions of magnesium chloride $(1 \mathrm{~mol} / \mathrm{l})$ and potassium hydrogen phosphate $(1 \mathrm{~mol} / \mathrm{l})$ are gradually added to the tested volume of the prepared sample, at the volume specified in the standard ČSN ISO 10705-3 [4]. Sodium hydroxide solution (2 mol/l) is added dropwise until visible turbidity is obtained, while simultaneously checking the $\mathrm{pH}$ value, which should not exceed 8.6. The suspension is stirred slowly for about 15 minutes, during which the resulting flakes settle for about 30 minutes. After carefully withdrawing the supernatant, the thin sediment is concentrated by low speed centrifugation (relative centrifugal acceleration $R C F=1,000 \mathrm{~g}$ ) for 15 minutes. After decanting the supernatant, the sediment is resuspended in peptone water with sodium chloride and vigorous shaking. Determination of somatic coliphages is then performed according to the standard ČSN EN ISO 10705-2 [3]. The effect of $\mathrm{pH}$ on flocculation ( $\mathrm{pH}: 7.6 ; 8.0 ; 8.3 ; 8.6$, and 9.0) was also monitored to test the effectiveness of the concentration method.

The membrane filtration method consists of filtering a given volume of sample through an electronegative filter made of a mixture of cellulose acetate and cellulose nitrate, with a pore size of $0.22 \mu \mathrm{m}$ and a diameter of $47 \mathrm{~mm}$. Filtration is preceded by the addition of magnesium chloride solution. The filter is then cut into about 8 smaller parts and placed in a glass flask with an elution solution ( $1 \%$ bovine extract, $0.5 \mathrm{~mol} / \mathrm{l} \mathrm{NaCl}, 3 \%$ Tween 80 ), which is placed in an ultrasonic bath for about 4 minutes. Simultaneously, the somatic coliphages released into the elution solution and collected on the filters are determined. As part of testing the effectiveness of the method, the effect of the composition of the elution solution was also monitored (here: $1 \%$ bovine extract, $0.5 \mathrm{~mol} / \mathrm{l} \mathrm{NaCl} ; 1 \%$ bovine extract, $0.5 \mathrm{~mol} / / \mathrm{NaCl}, 3 \%$ Tween 80; 3\% bovine extract, $0.5 \mathrm{~mol} / / \mathrm{NaCl} ; 3 \%$ bovine extract, $0.5 \mathrm{~mol} / \mathrm{l} \mathrm{NaCl}, 3 \%$ Tween 80 ).

\section{RESULTS AND DISCUSSION}

The presence of somatic coliphages in the aquatic environment usually indicates pollution caused by an animal or human feces. Although they are natural host strains of somatic coliphages of E. coli bacterium, some studies have found that they may use other related bacterial species that are not of fecal origin for their replication [5]. Comparison of the occurrence of somatic coliphages in differently loaded waters, or in drinking water, surface water, grey water, and in treated wastewater (effluent from WWTP) is evident in Table 1. Determination was performed according to the procedure specified in the standard ČSN EN ISO 10705-2 [3]. In the tested surface waters, the numbers of somatic coliphages ranged from 0 to $25 \mathrm{PFU} / \mathrm{ml}$. Due to the fact that different types of surface water (flowing, standing) from different sites were taken and analysed, the average value of the number of PFU is not given. Of the tested waters, the highest numbers of somatic coliphages were found in effluent from wastewater treatment plants. A total of 6 different WWTPs were tested, while the 
je výskyt koliformních bakterií a případně E. coli obvyklý a byl v analyzovaných vzorcích potvrzen (viz tabulka 1), nebyla přítomnost somatických kolifágů kultivačně potvrzena. $V$ pitných vodách odebíraných z kohoutku u spotřebitele nebyla podle očekávání prítomnost somatických kolifágů zjištěna.

Tabulka 1. Výskyt somatických kolifágů v různých druzích vod - postup podle normy ČSN EN ISO 10705-2 [3]

\begin{tabular}{llll}
\multirow{2}{*}{ Druh vody } & $\begin{array}{l}\text { Průměrná } \\
\text { hodnota SK }\end{array}$ & $\begin{array}{l}\text { Minimální } \\
\text { hodnota SK }\end{array}$ & $\begin{array}{l}\text { Maximální } \\
\text { hodnota SK }\end{array}$ \\
\cline { 2 - 4 } & PTJ/ml & PTJ/ml & PTJ/mI \\
\hline pitná voda & 0 & 0 & 0 \\
\hline povrchová voda & $x^{*}$ & 0 & 25 \\
\hline šedá voda & 0 & 0 & 0 \\
\hline $\begin{array}{l}\text { vyčištěná odpadní } \\
\text { voda z ČOV }\end{array}$ & 42 & 8 & 84 \\
*Poznámka: Pro povrchové vody není uvedena prümérná hodnota z důvodu odběru \\
vzorkůzrůzných lokalit.
\end{tabular}

Vzhledem k tomu, že stanovení somatických kolifágů podle normy ČSN EN ISO 10705-2 [3] využívá standardně k analýze 1 ml vzorku, může tento postup vést k chybě a nesprávné interpretaci výsledků zkoušky při analýze vod s nižší koncentrací kolifágů a nižším mikrobiálním znečištěním. Vody méně mikrobiálně oživené, např. povrchové stojaté a tekoucí vody, šedé vody a pitné vody vyžadují předúpravu vzorku metodou jejich zkoncentrování podle ČSN ISO 10705-3 [4]. Použití spolehlivé metody zkoncentrování somatických kolifágů ve vzorku vody před jeho analýzou může účinnost detekce výrazně zlepšit. $V$ grafech na obr. 1-3 jsou uvedeny laboratorně zjištěné účinnosti koncentračních metod flokulace hydroxidem hořečnatým a membránové filtrace. U metody flokulace hydroxidem hořečnatým se účinnost zkoncentrování somatických kolifágů pohybovala v rozmezí od cca 32 do $64 \%$, prričemž byla zjištěna její závislost na hodnotě pH. Nejvyšší počty somatických kolifágů byly stanoveny u vzorků s pH 8,0 (účinnost zkoncentrování cca 64 \%) a 8,3 (účinnost zkoncentrování cca $64 \%$ ), viz obr. 1. Lze předpokládat, že účinnost záchytu kolifágů do vloček bude vyšší u koncentrování více organicky zatížené vody. Výrazně vyšší účinnost vykazovala oproti flokulaci metoda membránové filtrace. V závislosti na použitém elučním roztoku se účinnost pohybovala v rozmezí cca 40 až 100 \%, viz obr. 2. Zásadní je pro uvolnění somatických kolifágů z membránových filtrů obsah neiontového tenzidu Tween 80 v elučním roztoku. S jeho pomocí bylo ve většině prípadů dosahováno cca 100 \% účinnosti zkoncentrování somatických kolifágů. Jak je patrné z obr. 3, má v postupu koncentrování membránovou filtrací dưležitý význam také chlorid hořečnatý, který je ke vzorku přidáván před jeho zfiltrováním. Bez jeho použití se prưměrné účinnosti záchytu somatických kolifágů v závislosti na elučním roztoku pohybovaly v rozmezí 19-52%. Multivalentní kationty, jako je $\mathrm{Mg}^{2+}, \mathrm{Ca}^{2+}$ a $\mathrm{Al}^{3+}$, umožňují př̌i nižším pH účinnější adsorpci kolifágů na elektronegativních membránových filtrech [7]. findings of somatic coliphages in the effluent ranged from 8 to $84 \mathrm{PFU} / \mathrm{ml}$ with an average value of about $42 \mathrm{PFU} / \mathrm{ml}$. Laboratory somatic coliphages have not yet been detected in the wastewater at the WWTP inflow (the reason is the increased occurrence of the accompanying microflora, which disturbs the plaque reading during evaluation). For the sake of completeness, the professional literature reports the numbers of somatic coliphages on inflows to WWTP in the range from $5 \cdot 10^{6} \mathrm{PFU} / 100 \mathrm{ml}$ to $5 \cdot 10^{7} \mathrm{PFU} / 100 \mathrm{ml}$ [6]. In grey water samples, in which the occurrence of coliform bacteria and possibly E. coli is common and was confirmed in the analysed samples (see Table 1), the presence of somatic coliphages was not confirmed by cultivation. As expected, the presence of somatic coliphages was not detected in drinking water taken from the consumer's tap.

Table 1. Occurrence of somatic coliphages in various types of waters - procedure according to the standard ČSN EN ISO 10705-2 [3]

\begin{tabular}{|c|c|c|c|}
\hline \multirow{2}{*}{ Type of water } & Average SC & Minimum SC & Maximum SC \\
\hline & PFU/mI & PFU/ml & PFU/ml \\
\hline Drinking water & 0 & 0 & 0 \\
\hline Surface water & $x^{*}$ & 0 & 25 \\
\hline Grey water & 0 & 0 & 0 \\
\hline $\begin{array}{l}\text { Treated wastewater } \\
\text { from WWTP }\end{array}$ & 42 & 8 & 84 \\
\hline
\end{tabular}

"Note: For surface waters, no average value is given due to sampling from different sites.

Due to the fact that the determination of somatic coliphages according to the standard ČSN EN ISO 10705-2 [3] uses $1 \mathrm{ml}$ of sample for analysis, this procedure can lead to error and incorrect interpretation of test results in the analysis of waters with lower coliphage concentration and lower microbial contamination. Waters with less microbial activity (e.g. surface standing and running water, grey water, and drinking water) require pre-treatment of the sample by the method of their concentration according to ČSN ISO 10705-3 [4]. The use of a reliable method of concentrating somatic coliphages in a water sample before its analysis can significantly improve the detection efficiency. The graphs in Fig. 1 to 3 show the laboratory-determined efficiencies of concentration methods of magnesium hydroxide flocculation and membrane filtration. In the magnesium hydroxide flocculation method, the concentration efficiency of somatic coliphages ranged from about $32 \%$ to $64 \%$, and its $\mathrm{pH}$ dependence was found. The highest numbers of somatic coliphages were determined for samples with pH 8.0 (concentration efficiency about 64\%) and 8.3 (concentration efficiency about 64\%), see Fig. 1. It can be assumed that the efficiency of capturing coliphages in flakes will be higher when concentrating more organically loaded water. The membrane filtration method showed significantly higher efficiency compared to flocculation. Depending on the elution solution used, efficiency ranged from about $40 \%$ to $100 \%$, see Fig. 2 . The content of the non-ionic surfactant Tween 80 in the elution solution is essential for the release of somatic coliphages from the membrane filters. With its help, about $100 \%$ efficiency of the concentration of somatic coliphages was achieved in most cases. As can be seen in Fig. 3, magnesium chloride (which is added to the sample before it is filtered) is also important in the process of concentrating by membrane filtration. Without its use, average capture efficiencies of somatic coliphages ranged from 19\% to 52\%, depending on the elution solution. Multivalent cations such as $\mathrm{Mg}^{2+}, \mathrm{Ca}^{2+}$, and $\mathrm{Al}^{3+}$ allow more efficient adsorption of coliphages on electronegative membrane filters at lower $\mathrm{pH}$ [7]. 


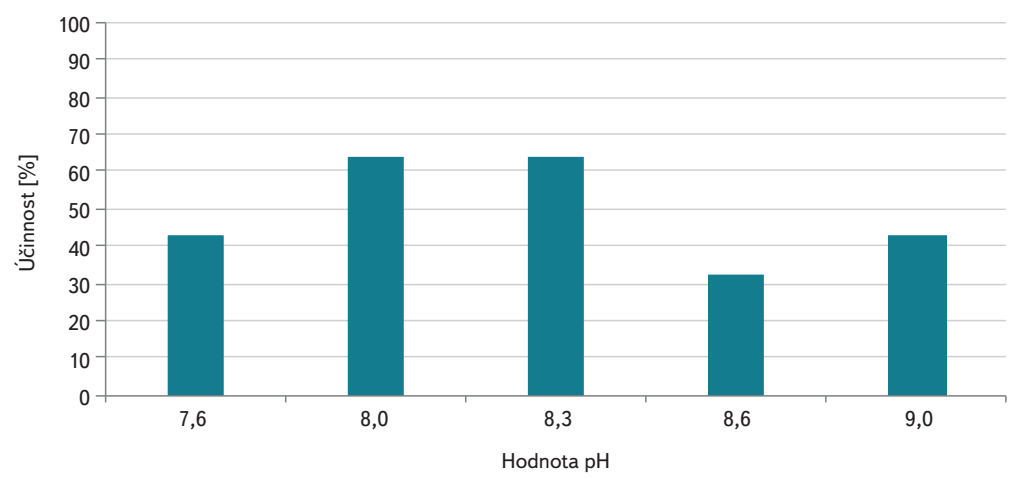

Obr. 1. Účinnost flokulace hydroxidem hořečnatým při zkoncentrování somatických kolifágů a vliv hodnoty $\mathrm{pH}$

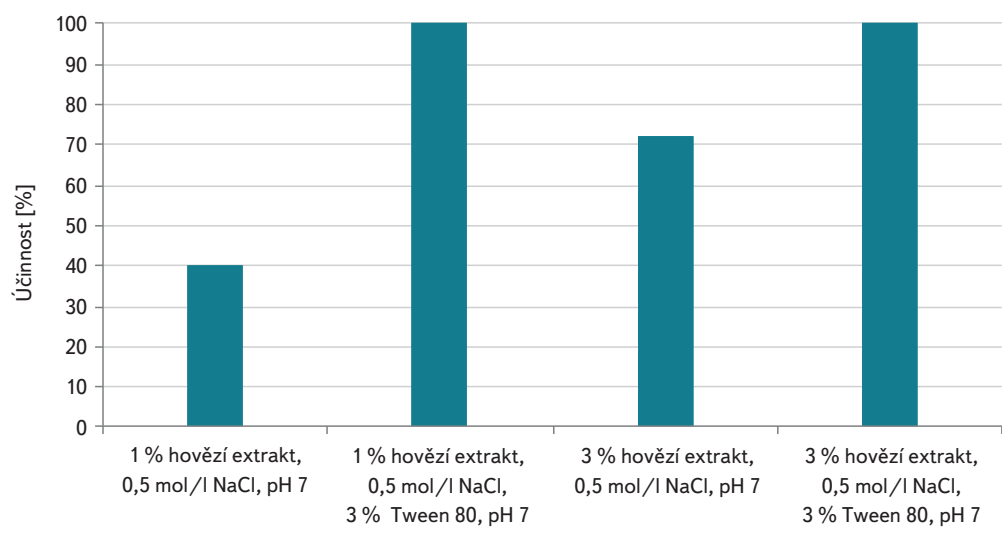

Obr. 2. Účinnost membránové filtrace podle postupu v ČSN ISO 10705-3 [4] (včetně přídavku $\mathrm{MgCl}_{2}$ ) při zkoncentrování somatických kolifágů a vliv rưzného elučního roztoku

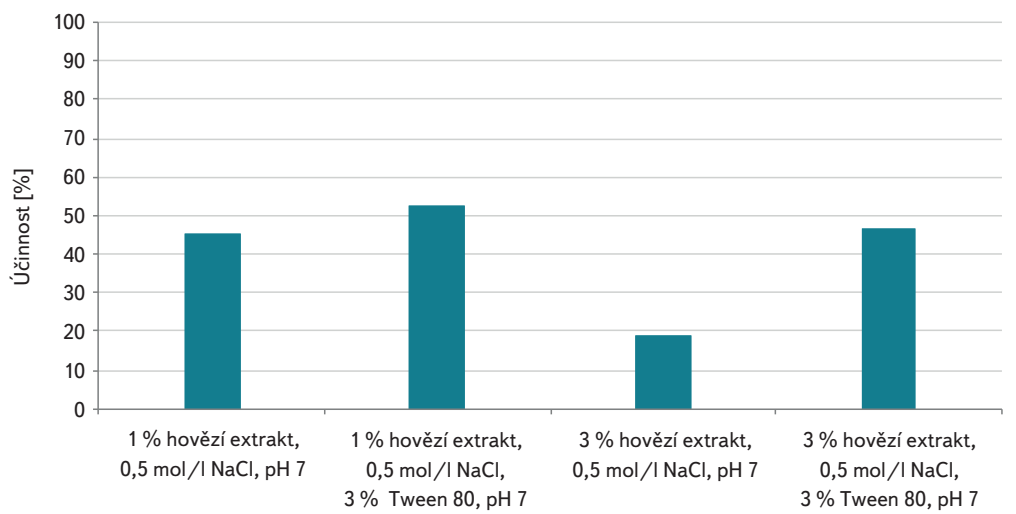

Obr. 3. Účinnost membránové filtrace podle postupu v ČSN ISO 10705-3 [4] (bez př́-

davku $\mathrm{MgCl}_{2}$ ) při zkoncentrování somatických kolifágů a vliv různého elučního roztoku

\section{PROBLÉMY ŘEŠENÉ PŘI STANOVENÍ SOMATICKÝCH KOLIFÁGŮ VE VODÁCH}

Stanovení somatických kolifágů bylo $v$ tomto prezentovaném prípadě, až na několik drobných modifikací, provedeno podle platné normy ČSN EN ISO 10705-2 [3]. Mezi tyto drobné modifikace Ize uvést např́klad pořadí aplikace jednotlivých složek do bakteriologických zkumavek. Zpočátku byla zejména kvưli rychlému tuhnutí (tvorbě hrudek) polotekutého média ssMSA dávána přednost prvotní aplikaci $1 \mathrm{ml}$ testovaného vzorku, $1 \mathrm{ml}$ inokulační kultury a až následně prídavku 2,5 ml média ssMSA. Nicméně, pomocí prováděných kontrolních slepých stanovení bylo zjištěno, že prvotní aplikací vzorku do bakteriologických

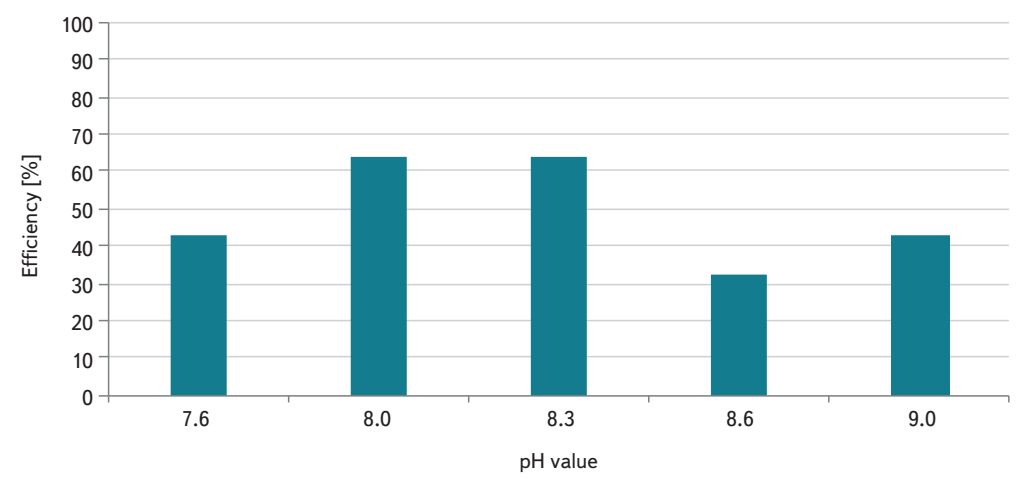

Fig. 1. Magnesium hydroxide flocculation efficiency in the concentration of somatic coliphages and the effect of $\mathrm{pH}$

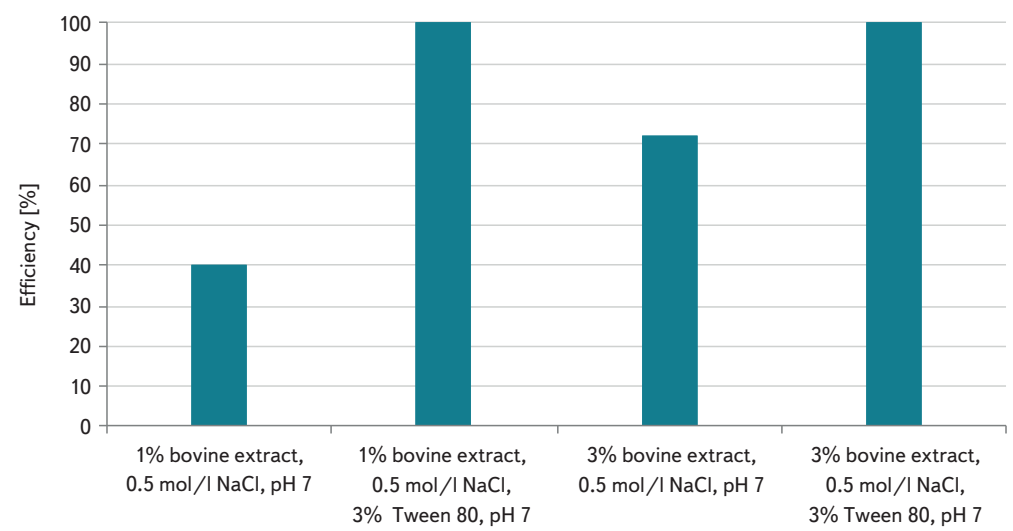

Fig. 2. Membrane filtration efficiency according to the procedure in ČSN ISO 10705-3 [4] (including the addition of $\mathrm{MgCl}_{2}$ ) in the concentration of somatic coliphages and the effect of different elution solution

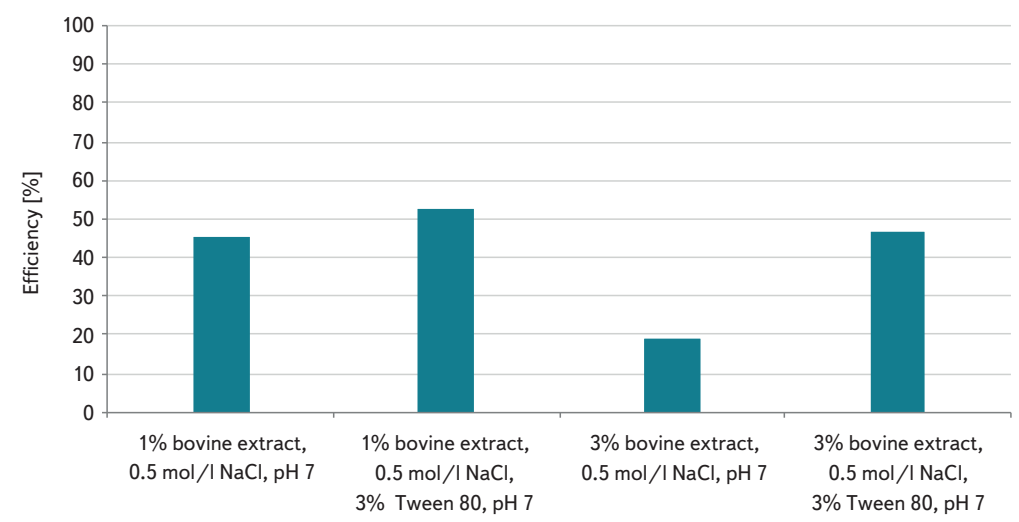

Fig. 3. Membrane filtration efficiency according to the procedure in ČSN ISO 10705-3 [4] (without addition of $\mathrm{MgCl}_{2}$ ) in the concentration of somatic coliphages and the effect of different elution solution

\section{PROBLEMS IN THE DETERMINATION OF SOMATIC COLIPHAGES IN WATERS}

In this presented case, the determination of somatic coliphages was performed, except for a few minor modifications, according to the valid standard ČSN EN ISO 10705-2 [3]. These minor modifications include, for example, the order of application of the individual components to the bacteriological tubes. Initially, mainly due to the rapid solidification (lumping) of the semi-liquid ssMSA medium, it was preferred to initially apply $1 \mathrm{ml}$ of the test sample, 
zkumavek mưže následně docházet ke křrižové kontaminaci inokulační kultury a ssMSA média kolifágy. Preferována byla tedy aplikace v následujícím pořadí: polotekuté médium ssMSA, inokulační kultura, testovaný vzorek. Řešením rychlého tuhnutí polotekutého ssMSA média může být bud" prídavek nižší navážky agaru s rizikem sesunutí vrchní vrstvy, nebo volba agaru o nižší teplotě tuhnutí. Prípadně je možné testovaný vzorek aplikovat do bakteriologických zkumavek takovým způsobem, aby pomalu stékal po vytemperované stěně zkumavky. Připravená směs byla vždy zlehka ručně promíchána kvůli zamezení vzniku vzduchových bublin a rychle nalita na kompletní médium MSA v Petriho miskách. Vyhodnocení, resp. odečet vzniklých plaků somatických kolifágů ruší nejen prítomnost vzduchových bublin, ale také př́tomnost kondenzované vody ulpěné na povrchu zatuhlé horní vrstvy (i v závěsné poloze). Z toho důvodu by měly být misky před inkubací nejprve předsušeny s částečně otevřenými víčky v termostatu (toto uvádí norma ČSN EN ISO 10705-2 [3] a je to důležité)

Při experimentálním ověření vybraných koncentračních metod popsaných v normě ČSN ISO 10705-3 [4] byly rovněž nalezeny některé problémové postupy. $\checkmark$ prípadě metody flokulace hydroxidem hořečnatým viditelně nedocházelo k sedimentaci všech vzniklých vloček. Z důvodu jejich co největšího záchytu bylo nutné odstřed’ovat větší objem vzorku, resp. bylo využíváno zkumavek o objemu $50 \mathrm{ml}$. Resuspendování vzniklého sedimentu $\vee$ peptonové vodě s obsahem $\mathrm{NaCl}$ může být $v$ menším objemu než $30 \mathrm{ml}$ problémové, vločky $\checkmark$ některých prípadech nebylo možné rozpustit ani intenzivním třepáním ani vortexováním (promíchání vírem kapaliny). V prípadě vzorku o nízké koncentraci kolifágů (<3 PTJ/ml), který je koncentrován flokulací, by bylo vhodné pracovat zároveň s jeho dvěma různými objemy, z nichž alespoň jeden umožní kvantifikaci plaků v $1 \mathrm{ml}$ (príp. $5 \mathrm{ml}$ ) zřed’ovacího roztoku o celkovém objemu $30 \mathrm{ml}$.

Oproti flokulaci je metoda membránové filtrace podstatně rychlejší a jednodušší. Nejvíce problémová je v tomto případě práce s filtry. Po provedené filtraci vzorku by měly být jednotlivé filtry rozstríhány na cca osm částí, upraveny $v$ ultrazvukové lázni a následně aplikovány lícem dolů na vrstvu média ssMSA s hostitelským kmenem. Zároveň s filtry by měl být stanoven eluční roztok metodou podle ČSN EN ISO 10705-2 [3]. Nejenže tato práce s filtry vyžaduje určitou zručnost s pinzetou, ale nepřináší ani očekávané výsledky, resp. somatické kolifágy v podobě plaků není možné z kultivovaných ploten s jistotou odečíst, viz obr. 4.
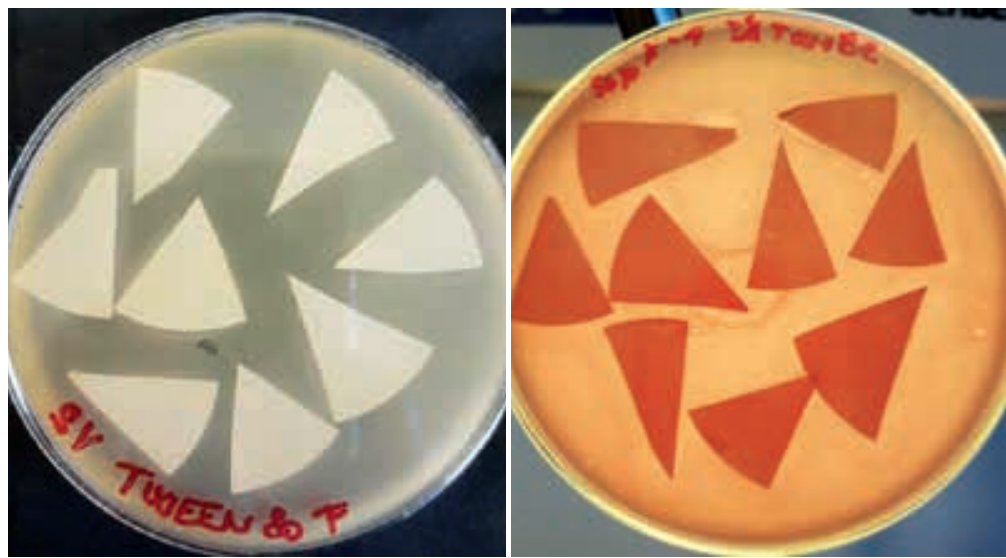

Obr. 4. Stanovení somatických kolifágů pomocí membránové filtrace - problematický odečet zachycených kolifágů na filtrech
$1 \mathrm{ml}$ of inoculum culture, and only subsequently to add $2.5 \mathrm{ml}$ of ssMSA medium. However, using control blanks, it has been found that initial application of the sample to bacteriological tubes can subsequently cross-contaminate the inoculum culture and the ssMSA medium with coliphages. Thus, application in the following order was preferred: semi-liquid SsMSA medium, inoculum culture, test sample. The solution to the rapid solidification of the semi-liquid SsMSA medium can be either the addition of a lower amount of agar (with the risk of the top layer sliding) or the choice of agar with a lower solidification temperature. Alternatively, the test sample can be applied to the bacteriological tubes in such a way that it slowly runs down the tempered wall of the tube. The prepared mixture was always lightly stirred by hand to prevent the formation of air bubbles and quickly poured onto the complete MSA medium in Petri dishes. Evaluation, or the reading of the formed plaques of somatic coliphages, is disturbed not only by the presence of air bubbles, but also by the presence of condensed water adhering to the surface of the solidified upper layer (even in the suspended position). For this reason, the dishes should first be pre-dried with the lids partially open in a laboratory thermostat before incubation (this is stated in the standard ČSN EN ISO 10705-2 [3] and it is important).

During the experimental verification of selected concentration methods described in the standard ČSN ISO 10705-3 [4], some problematic procedures were also found. In the case of the magnesium hydroxide flocculation method, sedimentation of all formed flakes did not occur visibly. To capture as many as possible, it was necessary to centrifuge a larger volume of sample, or $50 \mathrm{ml}$ tubes were used. Resuspension of the resulting sediment in peptone water containing $\mathrm{NaCl}$ can be problematic in less than $30 \mathrm{ml}$; in some cases it was not possible to dissolve the flakes either by vigorous shaking or by vortexing. In the case of a sample with a low concentration of coliphages ( $<3 \mathrm{PFU} / \mathrm{ml})$ which is concentrated by flocculation, it would be appropriate to work simultaneously with its two different volumes, at least one of which will allow quantification of plaques in $1 \mathrm{ml}$ (or $5 \mathrm{ml}$ ) of total volume of $30 \mathrm{ml}$.

Compared to flocculation, the membrane filtration method is significantly faster and simpler. The most problematic in this case is working with filters. After filtration of the sample, individual filters should be cut into about 8 parts, treated in an ultrasonic bath, and subsequently, applied face down to the layer of ssMSA medium with the host strain. Simultaneously with the filters, the elution solution should be determined by the method according to ČSN EN ISO 10705-2 [3]. Not only does this work with filters require a certain skill with tweezers, but it does not bring the expected results, or somatic coliphages in the form of plaques cannot be read with certainty from cultivated plates, see Fig. 4.
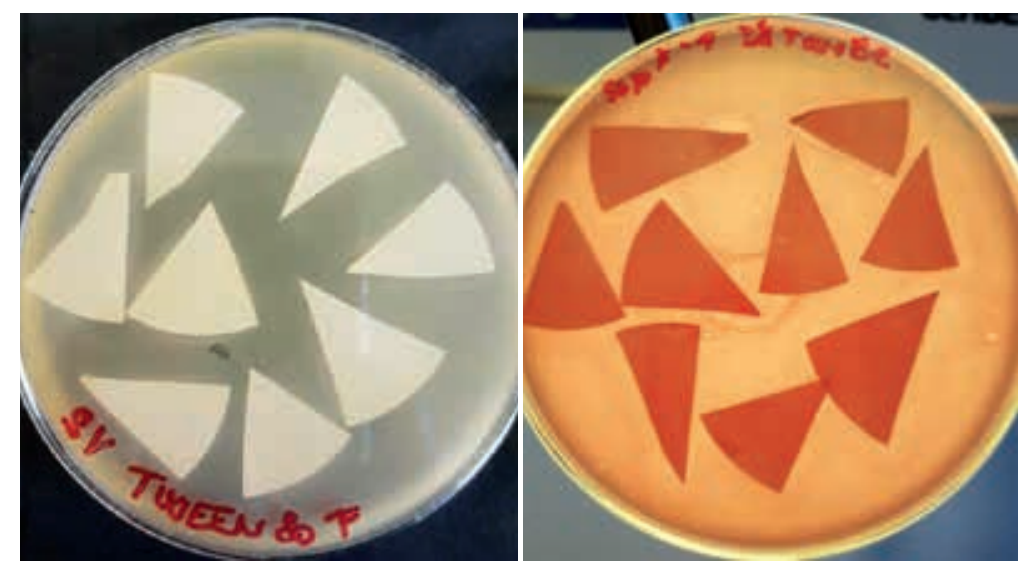

Fig. 4. Determination of somatic coliphages using membrane filtration - problematic enumeration of captured coliphages on filters 


\section{ZÁVĚR}

Indikace fekálního znečištění je dưležitým nástrojem pro zjištění zdravotn nezávadnosti vody. $V$ poslední době se pozornost přesouvá na další možné indikátorové organismy, resp. na somatické kolifágy, které mohou být využity při sledování účinnosti odstranění malých a více rezistentních částic (např. viry) procesem úpravy vody nebo čištění vod. $V$ rámci testů provedených $\vee$ mikrobiologické laboratoři Ústavu technologie vody a prostředí na VŠCHT Praha bylo zjištěno, že postup stanovení somatických kolifágů podle normy ČSN EN ISO 10705-2 [3] není vhodný pro pitné vody, šedé vody a některé povrchové vody, tedy tam, kde se očekává velmi nízká nebo nulová koncentrace kolifágů. U těchto typů vod bude ve většině prípadů nutné používat koncentrační metody uvedené v ČSN ISO 10705-3 [4], kterými dojde k převedení somatických kolifágů ze vzorku o větším objemu do objemu menšího. Metody jsou vybírány na základě objemu vzorku, obsahu částic nebo zákalu. Z prozatím získaných zkušeností s metodou flokulace hydroxidem hořečnatým a membránovou filtrací na elektronegativních filtrech Ize ríci, že druhá zmíněná metoda je schopna účinněji zkoncentrovat somatické kolifágy ze vzorku vody. Kromě toho, že je poměrně rychlá a prostorově méně náročná, bude pravděpodobně také provozními laboratořemi lépe proveditelná.

\section{Poděkování}

Tento výstup vznikl v rámci projektu Specifického vysokoškolského výzkumu - projekt č. A2_FTOP_2020_026.

\section{Literatura}

[1] Směrnice Evropského parlamentu a Rady (EU) 2020/2184 ze dne 16. prosince 2020 o jakosti vody určené k lidské spotřebě (přepracované znění). In: Úrední věštník Evropské unie, L 435, 23. 12. 2020 s. 1-62. Dostupné z: https://eur-lex.europa.eu/legal-content/CS/TXT/?uri=CELEX:32020L2184

[2] Nařizení Evropského parlamentu a Rady (EU) 2020/741 ze dne 25. května 2020 o minimálních požadavcích na opětovné využívání vody. In: Úřední věštník Evropské unie, L 177, 5. 6. 2020, s. 32-55. Dostupné z: https://eur-lex.europa.eu/legal-content/cs/TXT/?uri=CELEX:32020R0741

[3] ČSN EN ISO 10705-2. Jakost vod - Průkaz prítomnosti a kvantitativní stanovení bakteriofágů - Čás 2: Kvantitativní stanovení somatických kolifágů. Praha: ÚNMZ, 2002, 20 str.

[4] ČSN ISO 10705-3. Kvalita vod - Průkaz prítomnosti a kvantitativní stanovení bakteriofágů - Část 3 Validace metod pro zkoncentrování bakteriofágů z vody. Praha: ÚNMZ, 2020, s. 16

[5] BAUDIŠOVÁ, D. Metody mikrobiologického rozboru vody. 1st ed. 2017. ISBN 978-80-87402-61-0.

[6] JOFRE, J. et al. Coliphages as Model Organisms in the Characterization and Management of Water Resources. Water, 2016. Vol. 8, No. 5 .

[7] LANDE, V.W. and SINHA, V.R.P. Isolation, characterization and recovery of coliphages from sewage source. Journal of Global Biosciences, 2020, 9.5, p. 7442-7453.

\section{CONCLUSION}

The indication of fecal contamination is an important tool for determining the safety of water. Recently, attention has shifted to other possible indicator organisms, specifically s omatic coliphages, which c an b e u sed to m onitor the effectiveness of $r$ emoving $s$ mall a nd $m$ ore r esistant $p$ articles ( e.g. viruses) by water treatment or water purification. As part of tests performed in the microbiological laboratory of the Department of Water Technology and Environmental Engineering at the University of Chemistry and Technology in Prague, it was found that the procedure for determining somatic coliphages according to ČSN EN ISO 10705-2 [3] is not suitable for drinking water, grey water, and some surface waters; that is, where a very low or zero concentration of coliphages is expected. For these types of waters, in most cases it will be necessary to use the concentration methods specified in ČSN ISO 10705-3 [4], which will convert somatic coliphages from a sample with a larger volume to a smaller volume. Methods are selected based on sample volume, particle content or turbidity. From the experience gained so far with the method of magnesium hydroxide flocculation and membrane filtration on electronegative filters, it can be said that the latter method is able to more efficiently concentrate somatic coliphages from a water sample. In addition to being relatively fast and less space-consuming, it is also likely to be more feasible for operations laboratories.

\section{Acknowledgements}

This output was created within the project of Specific University Research - project No. A2_FTOP_2020_026.

\section{Autoři}

Ing. Jana Zuzáková

凶jana.zuzakova@vscht.cz

ORCID: 0000-0002-4060-2909

\section{Bc. David Janák \\ 凶david.janak@vscht.cz \\ ORCID: 0000-0001-9417-0278}

doc. RNDr. Jana Říhová Ambrožová, Ph.D.

凶jana.ambrozova@vscht.cz

ORCID: 0000-0002-1503-409X

Ústav technologie vody a prostředí,

Vysoká škola chemicko-technologická v Praze

Department of Water Technology and Environmental Engineering,

University of Chemistry and Technology, Prague

Př́spěvek prošel lektorským řizením.

DOI: 10.46555/VTEI.2020.11.002 